\title{
The Reasons of Conversion from Laparoscopic to Open Cholecystectomy: A Retrospective Analysis of 1950 Cases of a Single Tertiary-Center
}

\section{Laparoskopik Kolesistektomiden Açık Ameliyata Geçme Nedenleri: Üçüncü Basamak Merkezde 1950 Vakanın Retrospektif Analizi}

\author{
Yasin Kara, Mustafa Uygar Kalaycı \\ University of Health Sciences, Kanuni Sultan Süleyman Training and Research Hospital, Clinic of General Surgery, Istanbul, Turkey
}

\section{Abstract}

\begin{abstract}
Aim: We aimed to determine the reasons, rates and risk factors for the conversion to open cholecystectomies(CTOC) and making the statistical analysis with the demographic properties.
\end{abstract}

Methods: 1950 patients were included in this retrospective study; demographic properties (age,sex), performed abdominal operations, intraoperative and postoperative reasons for CTOC of patients were analysed.

Results: Of 1950 patients, 115 (5.9\%) had been CTOC in early or late period. The sex distrubition of the cases was 1540 (79\%) female and 410 (21\%) male ( F/M: 3.8). Rate of CTOC in male patients was significantly high ( $p$ : 0.009). There was no mortality. Reasons of CTOC were significant inflammation ( $n: 52)$, inadequate dissection of calot triangle due to fibrotic adhesions (n:31), adhesions of previous surgery $(n: 9)$, uncontrollable bleeding ( $n: 5)$, technical insufficiency $(n: 5)$, bile duct injury (n:5), anatomical variations (n:3), iatrogenic visceral injury $(n=2)$, gallbladder carcinoma $(n=1)$, isolated right posterior bile duct injury ( strasberg type C) (n:1) and common hepatic duct partial injury (n:1).

Conclusion: Significant inflammation, inadequate dissection of calot triangle due to fibrotic adhesions, adhesions due to previous surgery were three main reasons for conversion. Male gender and being elderly were associated with significantly increased rate of conversion.

Keywords: Laparoscopic cholecystectomy, open cholecystectomy, conversion to open, acute cholecystitis
Öz

Amaç: Hastanemizde yapılan laparoskopik kolesistektomi(LK)'lerin demografik özelliklerini belirlemeyi, açığa geçme nedenlerimizi ve oranlarımızı ortaya koymayı, olası komplikasyonlarımıza yaklaşımlarımııı literatür eşliğinde irdelemeyi amaçladık.

Yöntemler: Retrospektif olarak incelenen 1950 hastanın yaş, cinsiyet, ameliyat öncesi tanı, laparoskopik olarak tamamlanan ve açık ameliyata geçilen hasta sayıları ve bu hastaların demografik özellikleri, açık ameliyata geçiş nedenleri,oluşan komplikasyonlarımız ve bunlara yaklaşımlarımız değerlendirilmiştir

Bulgular: 1950 hastanın 115' inde (\% 5.9) erken veya geç dönemde laparotomiye geçildiği tesbit edildi. Olguların 1540 ü kadın (\% 79) ve 410 u erkektir (\%21), kadın/erkek oranı 3.8 idi. Açı̆̆a geçilen olguların 60' i erkek, 55 ' i kadındı.Erkek hastalarda açığa geçiş oranı anlamlı olarak yüksekti(P:0.009). 106 hastamızda komplikasyon olmadan açığa geçilirken 9 hastamızda LK ye bağlı majör komplikasyonlar nedeni ile açığa geçilmiştir.Mortalite yoktur. Açı̆̆a geçme nedenleri mevcut ciddi inflamasyon nedeni ile diseksiyon güçlüğü(n=52), calot üçgeninin ortaya konamaması( $n=31)$, geçirilmiş ameliyata bağlı adezyonlar $(n=9)$, durdurulamayan $\operatorname{kanama}(n=5)$, teknik yetersizlik $(n=5)$, koledok yaralanması $(n=5)$, anatomik varyasyonlar $(n=3)$, iatrojenik organ yaralanması $(n=2)$, safra kesesi tümörü( $n=1)$, izole sağ posterior sektörel duktus yaralanması (strasberg tip c) $(n=1)$ ve ortak hepatik kanal parsiyel kesisi' $\operatorname{dir}(n=1)$.

Sonuç: Açığa dönüşün en sık nedenleri akut kolesistit atağına bağlı ciddi inflamasyon, fibrotik yapışıklıklara bağlı calot üçgeninin ortaya konamaması ve geçirilmiş cerrahiye bağı yapışı|klıklardı. Erkek cinsiyet ve ileri yaşta açığa geçilen grupta istatistiksel olarak anlamlı yüksek bulundu.

Anahtar Sözcükler: Laparoskopik kolesistektomi, açık kolesistektomi, açığa dönüş, akut kolesistit
Yazışma Adresi/Address for Correspondence: Yasin Kara

University of Health Sciences, Kanuni Sultan Süleyman Training and Research Hospital, Clinic of General Surgery, İstanbul, Turkey

Tel.: +90 5056410226 E-posta: yasinkara32windowslive.com

Geliş Tarihi/Received: 02 October 2018 Kabul Tarihi/Accepted: 16 November 2018
'Copyright 2018 by The Medical Bulletin of University of Health Sciences Haseki Training and Research Hospital
The Medical Bulletin of Haseki published by Galenos Yayınevi.

•Telif Hakkı 2017 Sağlık Bilimleri Üniversitesi Haseki Eğitim ve Araștırma Hastanesi Haseki Tıp Bülteni, Galenos Yayınevi tarafından basılmıştır. 


\section{Introduction}

Laparoscopic cholecystectomy (LC) as a minimally invasive approach has become the most common intraabdominal surgery performed in all around the world $(1,2)$. Laparoscopic cholecystectomy (LC) because of some advantages like less postoperative pain, short hospitalization, early return to work, good cosmetic results has become gold standard for the treatment of symptomatic benign gallbladder diseases $(1,2)$.

Recent studies have shown that $4.9 \%$ of traditional laparoscopic cholecystectomies are converted to open surgery for a variety of reasons, ranging from unclear anatomy to excessive inflammation and adhesions from prior abdominal operations $(3,4)$.

A retrospective review of medical records was undertaken to identify all laparoscopic and converted to open cholecystectomy(CTOC) performed at our single center over a 7-year period. We aimed to determine and present the reasons, rates and risk factors of the conversion and our treatment approaches to several complications in the light of literature.

\section{Methods}

In this retrospective study, patients aged 17 years and older who had LC or LCOC in our general surgery clinic between March 2011 and August 2018 were included. Total number of 2076 patients were collected from hospital archives and electronic hospital records. Seventysix patients in whom the reason for CTOC was anesthetic complications or presence of severe co-morbidities and 50 patients with incomplete data were excluded from the study.

All the datas of 1950 patients were recorded and descriptive statisical analytic datas were obtained. The research was prepared according to the principles of Helsinki declarations. All LC had been performed by experienced general surgeons of our clinic with a standard 4 trocar technique and 12-15 mmHg CO2 intraabdominal pressure. Patients are divided into two groups as group 1: Laparoscopic cholecystectomy (LC) (group 1, n:1835) and group 2: ones converted from laparoscopic to open conversion (LCOC) (group 2, n:115). Demographic properties (age,sex), previous abdominal operations, intraoperative and postoperative reasons for conversion to open surgery of in the groups were analysed. Statistical analyses were made by Fisher's exact test, Student-t and the Chi-square tests.

\section{Results}

Of 1950 patients who underwent LC, 1540 were female (79\%), and 410 were male (21\%). F/M ratio was 3.8 . Median age was $49.5 \pm 12.6$ (24-76), median operation time was 55 (25-225) minutes. Median postoperative hospital stay was 1.3 days (14 hours -14 days).

In sixty of 1540 female patients (3.9\%) and 55 of 410 males ( $13.4 \%$ ), in total 115 patients CTOC occured. Conversion rate in male patients was statistically significant $(p<0.001)$ when compared to female ones. Median age of patients in group of LCOC and LC group was $51.3 \pm 13.5$ and $41.5 \pm 12.7$ years respectively. When compared with LC group, median age in LCOC group was higher which was found statistically significant $(p=0.009)$.

Indication of operations were cholelithiasis in 1764 patients (90.4\%), acute cholecysitis(AC) in 155 patients $(7.9 \%)$, gallbladder polyps in 21 patients $(1 \%)$ and acalculous cholecystitis in $10(0.5 \%)$ patients. In a 71 years old female patient who was operated with the diagnosis of $A C$, gallbladder carcinoma was encountered by frozen section intraoperatively and extended cholecystectomy was performed.

In 52 (33.5\%) of AC patients, CTOC was recorded. In patients with gallbladder polyp or acalculous cholecystitis, conversion to open surgery was not seen. Rate of CTOC was significantly higher in patients operated due to $A C$.

Sixty-eight of patients operated for AC were female (4.4\% of all female patients), 87 was male ( $21 \%$ of male patients). So operational rate of male patients due to $A C$ was much more higher than female patients $(P<0.001)$.

Mean ages of patients operated for $A C$ and cholelithiasis were $51.2 \pm 13.0$ and $48.4 \pm 13.1$, respectively. Mean age of patients operated for $A C$ was higher and that was statistically significant $(\mathrm{P}<0.05)$.

In 115 patients, CTOC or delayed laparatomy decision was due to 9 different reasons as difficulty in dissection due to present significant inflammation (n:52), inadequate dissection of calot triangle due to fibrotic adhesions ( $\mathrm{n}: 17)$, adhesions due to previous surgery (n:9), uncontrollable bleeding in gallbladder bed (n:5), bile duct injury (n:5), technical insufficiency (n:3), visceral injury $(n: 2)$ isolated right posterior bile duct injury ( Strasberg type $C)(n: 1)$ and common hepatic duct partial injury (n:1) (Table 1).

In LCOC group, while decision of CTOC was made intraoperatively in 111 patients, in 4 patients, laparotomy decision was made 2-6 days after LC. Median ages of females and males in LCOC group were 46.8 \pm 17.1 and $53 \pm 16.3$ years, respectively and the difference was statistically significant $(p<0.001)$. One patient underwent laparotomy with the diagnosis of biliary peritonitis at the postoperative 4th day, was sent to a higher hepatobiliary center with the diagnosis of Bismuth type 4 bile duct injury. In one patient, due to delayed bismuth type 3 injury and bile leakage Roux-en-Y hepaticojejunostomy(RNYH) was applied at the postoperative 6th day. In three Bismuth type 1, 2 and 3 injuries, RNYH was performed. In one type 


\begin{tabular}{|l|l|l|}
\hline \multicolumn{3}{|c|}{ Table 1. The reasons of conversion to open cholecystectomy } \\
\hline $\begin{array}{l}\text { The reasons of conversion to open chole- } \\
\text { cystectomy }\end{array}$ & $\mathbf{n}$ & $\%$ \\
\hline Significant inflammation & 52 & 45.2 \\
\hline Fibrotic adhesions in calot triangle & 31 & 27 \\
\hline Adhesions due to previous operations & 9 & 7.8 \\
\hline latrogenic bile duct injuries & 7 & 6 \\
\hline Uncontrollable bleeding in gallbladder bed & 5 & 4.3 \\
\hline Technical insufficiency & 5 & 4.3 \\
\hline Anatomical variations & 3 & 2.6 \\
\hline Visceral injuries & 2 & 1.7 \\
\hline Carcinoma of the gallbladder & 1 & 0.86 \\
\hline Total & 115 & 100 \\
\hline
\end{tabular}

1 injury end to end anastamosis over t-tube with ERCP and stenting was done. In one patient, ongoing bleeding was the reason to laparatomy at postoperative 4th day in whom hemostasis and suturing was applied. One patient was operated due to acute abdomen at the postoperative 2nd day and iatrogenic duodenal injury was treated with primary repair and omentopexy (Table 2 and Table 3).

CTOC rate was $12.5 \%(25 / 200)$ in the first 200 cases, and later the rate declined to $5.1 \%(90 / 1750)$. Difference between the rates was not found statistically significant $(p=0.137)$.

\section{Discussion}

Laparoscopic cholecystectomy (LC) from the early 1990s began to replace open cholecystectomy. In the following years laparoscopic intervention has become routine in cholecystectomy cases. Laparoscopic cholecystectomy is the most commonly performed laparoscopic procedure in the world. It is superior in nearly every regard compared to open cholecystectomies. As a result of increased surgical experience and technical advantages laparoscopic treatment indications enlarged even in complicated cases. Despite all these developments, CTOC is required in some cases where LC is not safe and / or intraoperative complications are emerged $(5,6)$.

Recent studies have shown that $2-15 \%$ of traditional LCs are converted to open surgery for a variety of reasons (7). Sozen et al. reported that most common reasons of CTOC were adhesions in the calot triangle(30\%), difficulty in dissection(20\%), choledocholithiasis(20\%), and adhesions due to previous surgery (10\%) (8). In our study, significant inflammation due to acute cholecystitis $(45.2 \%)$, fibrotic adhesions in calot triangle (27\%), adhesions of previous surgery $(7.8 \%)$ and iatrogenic bile duct injury (6\%) were the most common four reasons of CTOC. Conversion to the open technique subjects patients to increased postoperative pain, potentially higher blood

\begin{tabular}{|l|l|}
\hline \multicolumn{2}{|l|}{ Table 2. Major complications } \\
\hline Complication & $\mathbf{n}$ \\
\hline Main bile duct injury & 5 \\
\hline İsolated right sectoral ductus injury (type c) & 1 \\
\hline Common hepatic ductus partial laceration & 1 \\
\hline jejunal injury & 1 \\
\hline Duodenal injury & 1 \\
\hline Total & 9 \\
\hline
\end{tabular}

\begin{tabular}{|c|c|}
\hline Complication & Treatment options \\
\hline $\begin{array}{l}\text { Main Bile duct } \\
\text { injuries (Complete } \\
\text { transection or } \\
\text { clipping) }\end{array}$ & $\begin{array}{l}\text { 1. Bismuth type } 3 \text { injury: Roux-en- } Y \\
\text { hepaticojejunostomy } \\
\text { 2. Bismuth type } 2 \text { injury: Roux-en- } Y \\
\text { hepaticojejunostomy } \\
\text { 3. Bismuth type } 4 \text { injury: After laparotomy and } \\
\text { drainage, send to the centre experienced } \\
\text { in hepatobiliary surgery } \\
\text { 4. Bismuth type } 1 \text { injury: End to end } \\
\text { anastomosis over T- tube plus ERCP and } \\
\text { stenting } \\
\text { 5. Bismuth type } 1 \text { injury: Roux-en-Y } \\
\text { hepaticojejunostomy }\end{array}$ \\
\hline $\begin{array}{l}\text { Isolated right } \\
\text { posterior sectoral } \\
\text { ductus injury ( } \\
\text { Strasberg type c) }\end{array}$ & $\begin{array}{l}\text { Injury was suspected with the ongoing bile } \\
\text { drainage and demostrated with MRCP and } \\
\text { treated conservatively by means of ERCP- } \\
\text { sphincterotomy- stenting. }\end{array}$ \\
\hline $\begin{array}{l}\text { Common Hepatic } \\
\text { Ductus partial } \\
\text { transection }\end{array}$ & $\begin{array}{l}\text { Primary suturing and ERCP-sphincterotomy- } \\
\text { stenting }\end{array}$ \\
\hline $\begin{array}{l}\text { jejunal injury } \\
\text { Duodenal injury }\end{array}$ & $\begin{array}{l}\text { Functional end to end anastomosis by using } \\
\text { lineer stappler } \\
\text { Primary repair and omentopexy }\end{array}$ \\
\hline $\begin{array}{l}\text { Uncontrollable } \\
\text { bleeding from } \\
\text { gallbladder bed }\end{array}$ & Hemostasis and suturing \\
\hline
\end{tabular}

loss, longer recovery time and time until return to work, and suboptimal cosmetic outcomes (9). Our CTOC rate is $7.9 \%$ which is compatible with literature. Male gender and older age were found to be associated with the increased CTOC rates in several studies (8). In our series, male and older patients have increased conversion rate which is statistically significant $(p<0.001)(p=0.009)$. Some studies suggest males have more adhesions due to less oestrogenic effect and late seeking for medical care for their complaints, pathophysiologically females may be more sensitive than males to the inflammatory changes of cholecystitis (10), also anatomical differences and dietary habits may be responsible from possible differences between two genders in cholelithiasis (10).

Although statistically insignificant, after the first two hundred patients our СTOC rates were decreased. As surgical technique and experience increases CTOC rates may decrease (11). Although some authors stated that learning curve for LC was 15 cases, this number was given as $10-50$ in other studies $(12,13)$. On the other hand, 
insistence of a experinced surgeon to complete the every difficult operations laparoscopically in spite of major risks may increase possibility of complications. In our series, CTOC ratio was $12.5 \%(25 / 200)$ in the first 200 cases, and later ratio was $5.1 \%(90 / 1750)$. Difference was not found statistically significant $(p=0.137)$. In 4 of our first 200 cases, we had major complications as 3 bile duct injuries and one visceral injury. We believe that consultation with an experienced surgeon, especially when experience is scarce, and routine usage of subhepatic drain may be useful in early diagnosis and prevention of complications.

Acute cholecystitis is an important risk factor or cause for conversion to open cholecysyectomy. Eldar S. et al. has reported that the rate of conversion to open is upto the $28 \%$ in hydrops or empyema of gallbladder and even upto $49 \%$ in acute gangrenous cholecystitis. Patients over 65 years of age, male gender and any form of $A C, W B C$ count over 13,000/cc were independently associated with a high CTOC rates .Patients with an operative delay of 96 hours or less from the onset of AC had a conversion rate of $23 \%$, whereas a delay of more than 96 hours was associated with a conversion rate of $47 \%$ (14). In our series, the rate of CTOC in patients with acute cholecystitis was 33.5\% and the rates of CTOC was found higher in male gender and ones with acute AC. In order to prevent CTOC and complications, we recommend to perform LC within 96 hours of the onset of AC. High risk patients with male sex, older age and /or complicated cholecystitis should be operated by surgeons experienced in laparoscopy to reduce the rate of $\mathrm{CTOC}$ and complications.

The incidence of bile duct injury (BDI) while performing an open cholecystectomy was as low as $0.1 \%$ to $0.2 \%$, but with the introduction of LC, it tripled to $0.4 \%$ to $0.6 \%$ of patients $(15,16)$. In our series, 7 bile duct injuries with the incidence of $0.35 \%$ occured, so it is compatible with the literature. In two patients with bismuth type 2 and 3 BDI, Roux-en-Y hepaticojejunostomy (RYHJ) was the treatment choice. One patient underwent laparotomy with the diagnosis of biliary peritonitis at the postoperative 4th day, was sent to higher hepatobiliary center with the diagnosis of bismuth type $4 \mathrm{BDI}$. In one patient, due to delayed bismuth type 3 injury and bile leakage RYHJ was applied at the postoperative 6 th day. In one type 1 injury end to end anastamosis over t-tube plus ERCP and stenting was done. Another type 1 injury was treated with RYHJ. Variation of opening of the aberrant right posterior sectoral(ARPS) duct directly to the cystic or common hepatic duct is seen in $2 \%$ to $5 \%$ of patients (17). There are a number of difficulties in the diagnosis and treatment of ARPS's BDI. In the ERCP, bile leakage cannot be seen and the diagnosis can be made as leakage from the luschka channels in the gallbladder bed. However, in the careful evaluation of ERCP, it can be seen that the right anterior sector of the liver (segments 5 and 8 ) is followed but there is no posterior (segment 6 and 7), MRCP can be diagnostic by showing that there is no connection between the transected duct and the main bile duct. There are discussions in the literature about treatment. Wojcicki et al. reported that they treated two cases with ARPS BDI by bilioenteric anastomosis and liver resection (18). Mazer et al. reported that they have successfully treated six cases of ARPS BDI with 2-14 months of follow-up (19). In our case, ERCP and MRCP were used for diagnosis. After sphincterotomy and stenting, biliary leakage was gradually decreased and laboratory and clinical parameters remained stable in two months followup. Conservative approach may be an important option in the treatment of ARPS BDI.There was no mortality. Any major BDI may result in significant morbidity, increased mortality, and financial burden on the patient. Studies have shown varying degree of success in reducing BDI by using Critical View of Safety (CVS) technique before clipping and cutting any structure (20). In CVS, three criteria are required to achieve this; the first states that the hepatocystic triangle; defined as the triangle formed by $C D$, the $C H D$, and inferior edge of the liver is cleared of fat and fibrous tissue. The CBD and CHD do not have to be exposed. The second states that the lower $1 / 3$ rd of the GB is separated from the liver to expose cystic plate. The third states that two and only two structures should be seen entering the $\mathrm{GB}(20)$. Yegiyants and Collins analyzed 3,000 patients and reported one BDI only (11). Sanjay et al. in 2010 studied using CVS technique after no BDI in 447 cholecystectomies and reported no BDIs (21). We think that with the use of CVS technique and selective intraoperative cholangiography(SIOC), BDI can be prevented. In our clinic, we also routinely perform CVS technique and SIOC in every LC. During the operation, the experienced physician should be consulted when necessary and there should be no hesitation to convert to open surgery if necessary.

In the literature, complications related to verres and trocar access are reported.

Deziel DJ et al, at 77.604 LC cases series, reported that incidence of bowel and vascular injuries were $0.14 \%$ and $0.25 \%$ respectively and most important cause of death after laparoscopic methods was intestinal perforation (22). In our series, we had two visceral injuries (duodenal and jejunal) with an incidence of $0.1 \%$, but no vascular injury. Jejunal injury was occured while entering abdomen of the patient with a history of previous abdominal surgery, by the way of hasson's open technique through the infraumbilical incision. It was treated by the functional end to end anastamosis with lineer stappler. Duodenal injury occured while the entrance of $10 \mathrm{~mm}$ epigastric 
trochar and realized at postoperative 2 nd day when the patient had developed acute abdomen. It was treated with primary repair and omentopexy.

\section{Conclusion}

In conclusion, the most frequent reasons for CTOC were present significant inflammation, inadequate dissection of calot triangle due to fibrotic adhesions, and adhesions due to previous surgery. Male gender and being elderly were found to be with significantly increased rate of CTOC. Acute cholecystitis seems to be the main reason of CTOC and BDIs. The Critical view of safety technique and selective IOSC should be used to avoid complications. In difficult or adherent cases where calot triangle structures cannot be exposed, subtotal cholecystectomy should be kept in mind. Conversion to open should not be thought as a failure but only the change of treatment modality.

\section{Authorship Contributions}

Concept: Y.K. Design: Y.K. Data Collection or Processing: Y.K. Analysis or Interpretation: Y.K., M.U. Literatur Search: Y.K., M.U. Writing: Y.K.

Conflict of Interest: No conflict of interest was declared by the authors.

Financial Disclosure: The authors declared that this study received no financial support.

\section{References}

1. Comitalo JB. Laparoscopic cholecystectomy and newer techniques of gallbladder removal. JSLS. 2012;16:406-412.

2. Gaillard M, Tranchart $H$, Lainas $P$, Dagher I. New minimally invasive approaches for cholecystectomy: review of literature. World J Gastrointest Surg. 2015 Oct 27;7(10):243-248.

3. Coffin SJ, Wrenn SM, Callas PW, Abu-Jaish W. Three decades later: investigating the rate of and risks for conversion from laparoscopic to open cholecystectomy. Surg Endosc. 2018 Feb; 32(2):923-929.

4. Livingston $E H$, Rege RV. A nationwide study of conversion from laparoscopic to open cholecystectomy. Am J Surg. 2004 Sept;188(3):205-211.

5. Shamiyeh A, Wayand W. Laparoscopic cholecystectomy: early and late complications and their treatment. Langenbecks Arch Surg 2004 Jun ; 389 (3):164- 171.

6. Chi-leungLiu, Sheung-tat F, Edward CSL, Chung-mau L, Kentman C. Factors affecting conversion of laparoscopic cholecystectomy to open surgery. ArchSurg 1996; 131:98101.

7. Pavlidis TE, Marakis GN, Ballas K et al. Risk factors influencing conversion of laparoscopic to open cholecystectomy. J Laparoendoscopic Adv Surg Tech A 2007 Aug; 17(4): 414418.

8. Sözen S, Emir S, Bali i. Laparoskopik Kolesistektomiden Açık Ameliyata Geçme Nedenleri Int J Basic Clin Med 2014;2(1):813.
9. Lipman JM, Claridge JA, Haridas $M$ et al. Preoperatif findings predict conversion from laparoscopic to open cholecystectomy. Surgery 2007; 142; 556-565.

10. Pekcici MR, Inceköy M, Torun V, Canlı AB. SSK Konya Bölge Hastanesinde laparoskopik kolesistektomi deneyimi ve açık ameliyata geçme nedenleri. Genel Tıp Derg 2005; 15 (1): 11 18.

11. Yegiyants S, Collins JC. Operative strategy can reduce the incidence of major bile duct injury in laparoscopic cholecystectomy. Am Surg. 2008 Oct;74(10): 985-987.

12. Akat AZ, Doğanay $M$, Koloğlu $M$ et al.Evaluation of 1000 laparoscopic cholecystectomies performed in one institution. T Klin J Med 2002; 22: 133-141.

13. Larson GM, Vitale GC, Casey J et al. Multipractice analysis of laparoscopic cholecystectomy in 1983 patients. Am J Surg 1992; 163: 221-226.

14. Eldar S, Sabo E, Nash E, Abrahamson J, Matter I. Laparoscopic cholecystectomy for acute cholecystitis: prospective trial. World J Surg. 1997 Jun;21(5):540-5.

15. McPartland KJ, Pomposelli JJ. latrogenic biliary injuries: classification, identification, and management. Surg. Clin. North Am. 2008 Dec;88(6):1329-43.

16. Sicklick JK, Camp MS, Lillemoe KD et al. Surgical management of bile duct injuries sustained during laparoscopic cholecystectomy: perioperative results in 200 patients. Ann Surg. 2005 May;241(5):786-92.

17. Lillemoe KD, Petrofski JA, Choti MA, Venbrux AC, Cameron $J \mathrm{~L}$. Isolated right segmental hepatic duct injury: a diagnostic and therapeutic challenge. J Gastrointest Surg. 2000;4:168177.

18. Wojcicki M, Patkowski W, Chmurowicz T et al. Isolated right posterior bile duct injury following cholectstectomy: report of two cases. World J Gastroenterol. 2013 Sep 28;19(36):61186121.

19. Mazer LM, Tapper EB, Sarmiento JM. Non-Operative Management of Right Posterior Sectoral Duct Injury Following Laparoscopic Cholecystectomy. J Gastrointest Surg. 2011 Jul; 15(7): 1237-1242.

20. Avgerinos C, Kelgiorgi D, Touloumis Z, Baltatzi L, Dervenis C. One thousand laparoscopic cholecystectomies in a single surgical unit using the "critical view of safety"technique. J Gastrointest Surg. 2009 Mar;13(3):498-503.

21. Sanjay P, Fulke JL, Exon DJ. 'Critical view of safety'as an alternative to routine intraoperative cholangiography during laparoscopic cholecystectomy for acute biliary pathology. J Gastrointest Surg. 2010 Aug;14(8):1280-1284.

22. Deizel DD, Millikan KW, Economou SG et al.Complications of laparoscopic cholecystectomy: A national survey of 4292 hospitals and analysis of 77604 cases. Am J Surg 1993;165:914. 